\title{
Trygdeepidemiologi - viktigere enn noen sinne
}

Velferdsstatens sikkerhetsnett er omfattende og komplekst. Kostnadene er kolossale, konsekvensene vidtrekkende, og det har de siste årene blitt gjennomført en rekke reformer for å oppnå økt arbeidsdeltakelse. Det er avgjørende at utredninger og evalueringer av årsaker, konsekvenser og effekter i størst mulig grad baseres på en vitenskapelig tilnærming. De viktigste bidragene til trygdeforskningen har $\mathrm{i}$ de siste tiårene kommet fra økonomi, sosialmedisin, sosiologi og epidemiologi.

Hvilken forskning omfattes av begrepet trygdeepidemiologi? En enhetlig definisjon savner vi, men det er rimelig å inkludere deskriptiv trygdeepidemiologi, årsaksforskning, intervensjonsforskning, forløpsforskning og diagnostikk (praksis) på sammenhengen mellom helse og trygdeytelser (1).

I dette nummeret av Norsk Epidemiologi ønsker vi å gi en bred presentasjon av forskning på trygdeepidemiologiske tema. Mest plass er det gitt til de omfattende områdene sykefravær og uføreytelser. Men vi har også inkludert forskning på legemiddelforbruk og helsetjenesteforskning. Hovedfokus er på norske forhold, men noe inkluderes fra andre nordiske land.

På grunn av en gjenstridig virkelighet, med vedvarende høyt nivå på omfanget av ulike trygdeytelser, har reformtempoet i de norske velferdsetatene vært forrykende de siste årene. I takt med dette, har bevilgninger til forskningsprosjekter økt noe og dette fører til en økning i nye prosjekter og en økning i antall artikler som blir publisert. Det blir derfor tiltagende viktig å få oppdaterte oversikter over hva som er rimelig sikker kunnskap. Vi har derfor valgt å innlede dette nummeret med fire større oversikter. Johan Bjørngaard m.fl. gir i en omfattende oversiktsartikkel et systematisk bilde av den epidemiologiske forskningen på uføreytelser i Norden. I den neste artikkelen drøfter Jon Petter Nossen tre ulike teoretiske modeller for å forklare sammenhengen mellom konjunkturer og sykefravær. Arnstein Mykletun og Simon Øverland gir deretter en oversikt over mulighetene for koblinger mellom helseundersøkelser og trygdedata, og gir eksempler på hvordan dette kan utføres alt etter som hvilket utgangspunkt forskningsprosjektet har. Den siste artikkelen i denne delen er en oversiktsartikkel av Grete Damberg, som sammenfatter viktige reformer og endringer $\mathrm{i}$ velferdsapparatet de siste årene. Vi tror disse fire artiklene kan danne et viktig bakteppe for fremtidig trygdeepidemiologisk forskning, og angi retning og fokus for fremtidig forskning.

Trygdeepidemiologisk forskning har mange metodiske utfordringer, og dette omhandles i de fem neste artiklene. Med bakgrunn i at sykefravær har blitt målt på over 50 ulike måter i forskjellige epidemiologiske studier, diskuterer og foreslår Gunnel Hensing fra en teoretisk tilnærming fem standardiserte mål på sykefravær. En slik standardisering vil gjøre det mye enklere å sammenligne resultater fra ulike studier. Det er også en metodeutfordring for trygdeepidemiologisk forskning, at mange trygdemottakere vandrer mellom gjentatte eller ulike ytelser. Hvordan dette kan håndteres statistisk, presenteres i en artikkel av Stein Atle Lie. Selv om Norge har stått i en særstilling ved å ha gode nasjonale registre for trygdeytelser, benytter mange studier seg av selvrapporterte data om sykefravær og uføretrygd. I to artikler av Irene Øyeflaten m.fl. og Ingeborg Hartz m.fl. undersøkes påliteligheten av slike selvrapporterte data i forhold til nasjonale registeropplysninger. Det er mange faktorer som settes $\mathrm{i}$ sammenheng med hvor vidt sykemeldte kommer tilbake $i$ arbeid. En av de viktige individuelle faktorene er mestring. Hvordan mestring skal måles, og relateres til tilbakegang til arbeid diskuteres av Magnus Odéen m.fl.

I kjerneområdet for trygdeepidemiologisk forskning ligger kohortstudier over risikofaktorer for sykefravær og uførepensjon. Petter Kristensen og Tor Bjerkedal beskriver i sin artikkel assosiasjonene mellom kjønn, sosiale ulikheter og sykefravær i en populasjonsbasert kohort av alle som var født i Norge 1967-76. Sturla Gjesdal undersøker risikofaktorer for overgang fra sykefravær til uføreytelser i en prospektiv nasjonal kohortstudie. I begge studiene er kjønnsforskjeller spesielt i søkelyset. I den følgende artikkelen har Anders Galaasen m.fl sett på en gruppe som sjelden får oppmerksomhet, nemlig de som får avslag på søknad om uføreytelse. I denne studien undersøkes både hvilke grupper som får avslag, og hvilke konsekvenser avslaget kan ha over et lengre perspektiv. Uførepensjonister er også tema i en studie av Ingeborg Hartz m.fl. som ser på de sosiale ulikhetene i medikamentbruk $\mathrm{i}$ denne gruppen.

Som et resultat av at stadig nye reformer blir innført og ulike tiltak settes i gang for at sykmeldte skal komme raskere tilbake i arbeid, er det viktig med forskning som skal vurdere effekten av disse tiltakene. Harald Elvsåshagen m.fl. beskriver i sin artikkel effekten av rask og standardisert henvisning til spesialist ved langtidssykmelding på grunn av muskel- og skjelettlidelser. Et forsøk med utvidet egenmeldingsordning i stor skala gjennomført i Kristiansand kommune, analyseres av Nils Fleten m.fl. i den siste artikkelen i dette temanummeret. Forfatterne referer til en tidligere egenmeldingsstudie av Taylor fra 1960-tallets England (2). Dette var en av de aller første trygdeepidemiologiske studiene som ble publisert - og dermed kan vi kanskje si at ringen er sluttet!

God fornøyelse!

1. Bruusgaard D, Claussen B, Brage S. Sykefravær, rehabilitering og uførepensjon i trygdemedisinsk forskning. I: Hansen HT. Kunnskapsstatus for den nordiske trygdeforskningen på 1990-tallet. Bergen: Stiftelsen for samfunns- og næringslivsforskning, 1999.

2. Taylor PJ. Self-certification for brief spells of sickness absence. $\operatorname{Br}$ Med J 1969; 1 (5637): 144-7. 


\section{Gjesteredaktører}

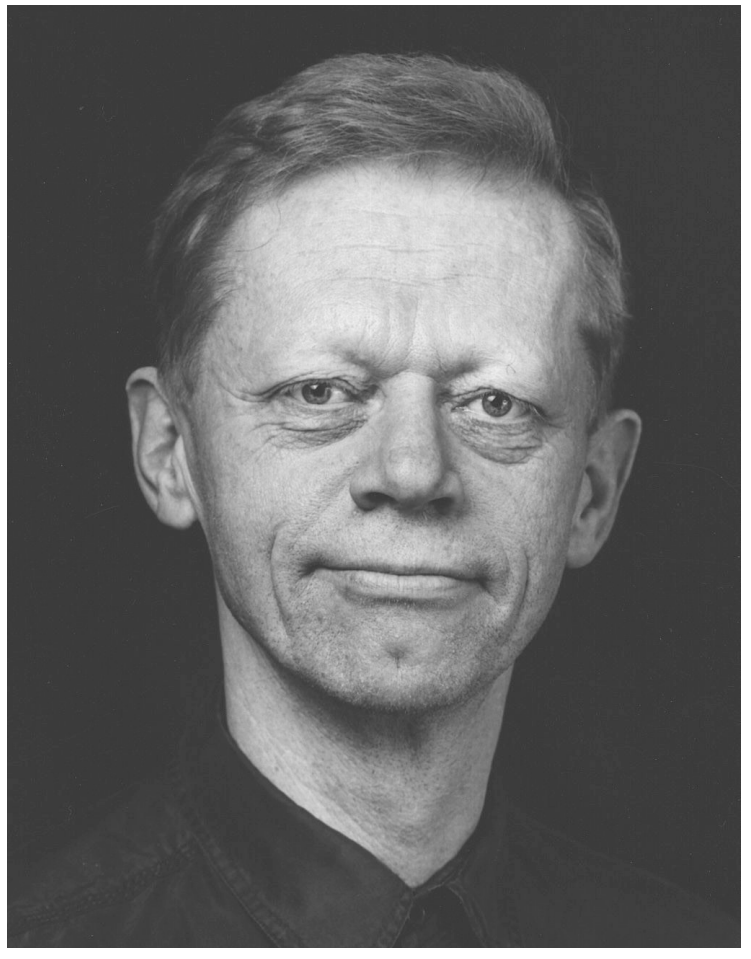

Søren Brage

Arbeids- og velferdsdirektoratet

Postboks 5, St Olavsplass 0130 Oslo

og

Institutt for allmenn- og samfunnsmedisin

Universitetet i Oslo

Postboks 1130 Blindern, 0318 Oslo

s.k.brage@medisin.uio.no

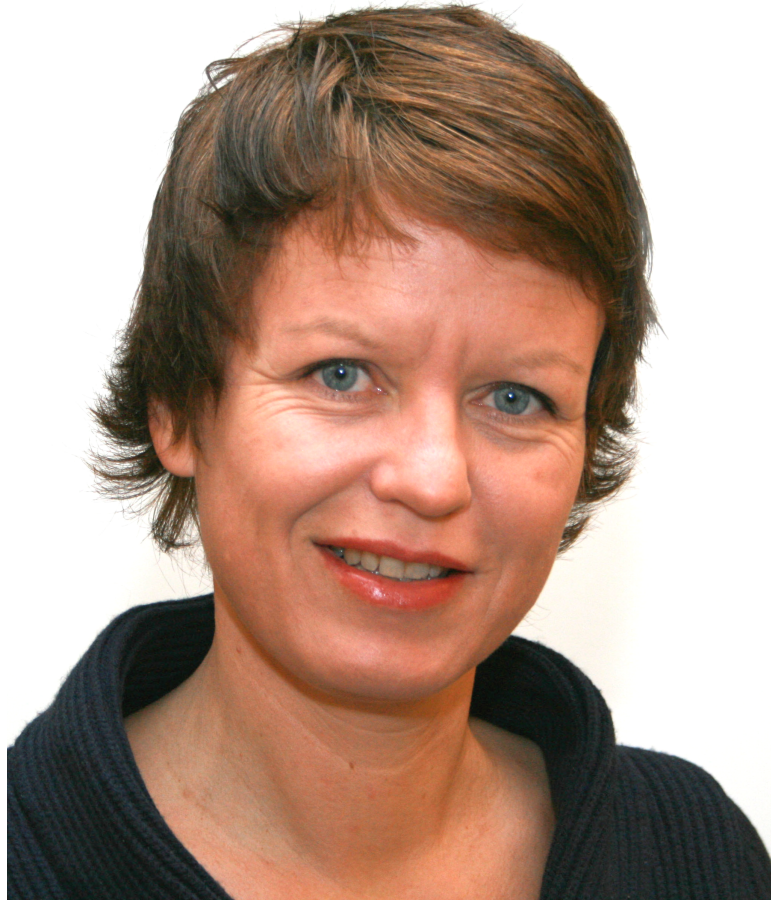

\section{Camilla Ihlebæk}

Forskergruppe for natur, helse og livskvalitet Institutt for husdyr- og akvakulturvitenskap Universitetet for miljø- og biovitenskap Postboks 5003, 1432 Ås

og

Uni helse,

Christiesgt 13, 5015 Bergen

camilla.ihlebak@umb.no 